\title{
Analysis of the Effect of Financial Subsidy on China's New Energy Vehicle Industry R \& D Activities
}

\author{
Junda Lin \\ Institute of Economics, Jinan University, Guangzhou, China \\ Email: da58632@163.com
}

How to cite this paper: Lin, J.D. (2019) Analysis of the Effect of Financial Subsidy on China's New Energy Vehicle Industry R \& D Activities. Modern Economy, 10, 96-107.

https://doi.org/10.4236/me.2019.101007

Received: December 14, 2018

Accepted: January 8, 2019

Published: January 11, 2019

Copyright $\odot 2019$ by author(s) and Scientific Research Publishing Inc. This work is licensed under the Creative Commons Attribution International License (CC BY 4.0).

http://creativecommons.org/licenses/by/4.0/

\section{(c) (i) Open Access}

\begin{abstract}
As a strategic emerging industry in China, new energy vehicles (NEV) industry has developed rapidly in recent years under the strong support of national industrial policies. In order to observe the effect of financial subsidies on $\mathrm{R} \&$ $\mathrm{D}$ activities of NEV companies in China, this paper cuts through the perspective of R \& D intensity of enterprises. According to the micro panel data of 75 listed companies in China's NEV industry chain from 2008 to 2016, empirical analysis shows that the financial subsidy has a positive effect on the R \& D intensity of the NEV industry chain enterprises, and the financial subsidies are more obvious for the new energy vehicle core component manufacturing industry when considering the sub-sectors. In addition, some other factors that may affect China's NEV industry have also been discussed. This puts forward some empirical evidence and policy recommendations for the direction of the country's further subsidy policy for the promotion of NEV industry innovation.
\end{abstract}

\section{Keywords}

Emerging Industries of Strategic Importance, NEV Industry, Fiscal Subsidies, $\mathrm{R} \& \mathrm{D}$ Intensity

\section{Introduction}

According to the statistics of the World Automobile Organization (OICA), by the end of 2014, the global car ownership has reached 1.236 billion. Even in the context of the slowdown in global economic growth after 2015, the world's total automobile production and sales volume has maintained steady growth. In 2015, the global growth rate remained at around $1 \%$. In recent decades, with the rapid growth of the number of traditional internal combustion engine vehicles, a series 
of problems related to energy shortage and environmental pollution have arisen. In this context, the use of new energy vehicles to replace traditional internal combustion engine vehicles has become one of the important ways to reduce the dependence of the automotive industry on oil and reduce pollutant emissions.

As a strategic emerging industry in China, the Chinese government has introduced policies on macro-oriented, R \& D support, investment management, market access, financial subsidies, industry management, and power batteries to promote the industrialization of the industry in an all-round way. With the support of policies, the production and sales of new energy vehicles have developed rapidly. In 2016, China became the world's largest new energy vehicle market. However, while China's new energy vehicle industry is developing at a high speed, it is relatively weak in the core technology of new energy vehicles. It is advanced in the world with its core indicators (pure power mileage, energy density, power system stability). There is still a certain gap in the level. In the policies and measures covered by the National Medium- and Long-Term Plan for Science and Technology Development (2006-2020), it is proposed to adopt fiscal and taxation policies that encourage enterprises to carry out scientific and technological innovation and research and development activities, reduce their research and development costs, and promote enterprises to actively carry out research and development, in order to increase the scientific output. Therefore, the Chinese government not only needs to stimulate the sales of new energy vehicles through fiscal and taxation policies, but also promotes the relevant enterprises to accelerate the research and development activities of new energy vehicles, improve the overall technical level of the industry, and convert the research and development expenditure into actual output.

In addition, in recent years, the industry has developed rapidly under the support of policies. At the same time, there have been vicious competitions such as false declarations, local protectionism, rent-seeking corruption, etc., in order to defraud high subsidies. In this context, the four ministries on February 13, 2018, the Notice on Adjusting and Improving the Financial Subsidy Policy for the Promotion and Application of New Energy Vehicles and the New Energy Vehicle Promotion Subsidy Program and Product Technical Requirements will be adjusted to the current new energy vehicle subsidy policy. Production and $\mathrm{R}$ \& D activities of new energy vehicles with high battery energy density and high cruising range, reducing or even eliminating subsidies for vehicles with lower technology content, thereby promoting the improvement of the overall industrial technology level, the subsidies for subsidies for new energy vehicles and subsidy targets The adjustment marks the targeted direction of the industry's support policies toward "supporting and strengthening". On April 1, 2018, the "Parallel Management Method for Average Fuel Consumption of Passenger Vehicle Enterprises and New Energy Vehicle Points". That is, the policy of parallel fuel consumption points (CAFC) and new energy vehicle points (NEV), on the one hand, requires traditional automobile companies to reduce fuel consumption, and at the same time requires enterprises to improve the production and sales of 
new energy vehicles. The key point is that the new energy vehicle points can be transferred between the car companies through market transactions. At the same time as the financial subsidies are abdicated, the market will support the production R \& D funds of new energy car companies in disguise.

What needs to be affirmed is that financial subsidies have promoted the market entry of new energy vehicles, and whether the financial subsidies of the new energy vehicle industry are really effective in stimulating enterprises to increase $\mathrm{R} \& \mathrm{D}$ activities, thus realizing their expectations of promoting the upgrading of industrial technology. The goal has not yet been determined. From the microscopic perspective, this paper uses the micro data of China's new energy auto industry listed companies from 2008 to 2016 to empirically analyze the effect of financial subsidies in China's new energy auto industry on the R \& D intensity of enterprises, and quantitatively analyze new data through empirical research on panel data. The impact of the development of the energy automobile industry will, to a certain extent, provide a certain theoretical and empirical basis for the formulation of new policies and the adjustment of existing policies in the future.

The study of relevant fiscal policies for the development of new energy vehicle industry combines the development of the industry with the government's fiscal and taxation support means, which involves microeconomic theory and fiscal policy theory. Research on the issues related to the financial subsidy policy of the new energy vehicle industry has certain reference value for perfecting China's fiscal policy theory system.

\section{Literature Review}

Griliches [1] suggests that the main source of knowledge and technology is research and development (R \& D). As a strategic emerging industry in China, the new energy vehicle industry relies more on advanced science and technology than traditional industries. Enterprises in this industry are required to continue technological R \& D activities to increase production and technology. And enterprise technology research and development (R \& D) activities help to improve the overall technical level of the industry and have positive externalities. Arrow [2] proposed that the non-exclusive and non-competitive nature of the market's non-validity and R \& D output makes the R \& D activity's revenue less than the social benefits generated by its $\mathrm{R} \& \mathrm{D}$ activities. The company is reluctant to engage in R \& D activities and achieve R \& D output. Less than its optimal level, and subsidies for corporate $\mathrm{R} \& \mathrm{D}$ activities can effectively alleviate the non-validity of the market for commodities. Since the R \& D expenditure is equivalent to the large fixed cost invested by the enterprise, the number of enterprises capable of conducting large-scale R \& D activities is small, resulting in incomplete competition in the market, which leads to inefficient resource allocation. On the basis of theoretical analysis and empirical combination, Chen Zhijun [3] puts forward the high cost of enterprise technology innovation investment, the uncertainty of research and development process and the spillover of innovation results, which determines the government's support for science and technology innovation. 
Need. This provides a theoretical basis for the government to provide fiscal incentives for R \& D activities and R \& D products of new energy auto industries.

At present, most studies believe that fiscal and tax incentives have a positive effect on corporate innovation. Among the research on financial subsidies, Chen Yufen et al. [4] used the panel and cross-section data of industrial enterprises above designated size in Zhejiang Province, and empirical research found that government R \& D subsidies and corporate R \& D investment have a significant positive correlation; He Yanlin, Zhu Weihao [5] took the 1466 listed companies of Shenzhen Stock Exchange as a sample, used Heckman's two-stage regression method to conduct empirical tests and concluded that the measures to promote $\mathrm{R} \& \mathrm{D}$ investment through financial subsidies in most regions of China are reasonable; Wang Zhou [6] using the iterative three-stage least squares (IT3SLS) empirical test, it is found that the government's innovation subsidies for strategic emerging industries are significant to the company's industry and innovation, and the impact on corporate performance is not significant, and there is a strong spillover effect. There are also a small number of studies that argue that financial subsidies do not have a significant positive correlation with $\mathrm{R} \& \mathrm{D}$ investment in some companies. For example, Gao Hongwei [7] used game analysis to demonstrate that financial subsidies have a crowding out effect on $R \& D$ investment of large state-owned enterprises; It is concluded that although the financial subsidy does not stimulate the R \& D investment activities of enterprises, it can increase the level of innovation output of enterprises by increasing the number of patents of enterprises [8]. In addition, some literatures have made some research on the effect of tax incentives. Chu Deyin [9] uses the micro-data of 2010-2014 listed companies in the seven major industries of strategic emerging industries to empirically prove that tax incentives and financial subsidies are the same for $\mathrm{R} \& \mathrm{D}$ investment. It has a significant positive impact; Dai Chen et al. [10] used the panel data of large and medium-sized industrial enterprises in various provinces and cities in 2002-2005 to prove that tax incentives have a stronger incentive effect on corporate R \& D investment than financial subsidies.

The effect of financial subsidies on the relative proportion of $\mathrm{R} \& \mathrm{D}$ investment in new energy auto companies has not yet been determined. In the context of relevant policies, this paper starts from the perspective of the intensity of R \& $\mathrm{D}$ investment in enterprises to empirically analyze the relationship of the two factors.

\section{Indicator Selection and Data Description}

The micro-data of the NEV companies used in this paper are derived from the 2008-2016 Wind-listed enterprise database and the annual report data published by various listed companies, with a total of 656 samples of 75 A-share listed companies. The reason for choosing a listed company as a sample is that the financial data of listed companies is relatively stable compared to non-listed companies. Excluding the following samples before analysis: 1) Excluding the 
data of listed companies that completed IPOs after 2010, because the financial data of some listed companies after 2010 is missing, to ensure that the panel data is balanced panel data; 2) Excluding the important indicator data is empty or there are obvious abnormal samples, because these samples are not conducive to data processing, and its true reliability is yet to be verified; 3) Excluding companies that are delisted during this time period, these enterprises often operate There are some problems, and financial indicators are often abnormal. For the lack of partial data, it will be recorded as 0 in this paper. Because the proportion of missing is small, it may not affect the accuracy of the empirical test.

Through the above corresponding processing, $8.00 \%$ of the samples are eliminated, and the representativeness of the samples is not affected after the rejection, and finally 621 sample data are obtained. Data processing and empirical analysis were implemented using Stata14.0. According to the availability of data and the needs of research, the following indicators were selected and constructed:

1) Core explanatory variables: $\mathrm{R} \& \mathrm{D}$ investment intensity rdintensity. Enterprise R \& D activities can generally be measured by two indicators: patent output and $\mathrm{R} \& \mathrm{D}$ expenses. Considering that the definition of patents in this emerging industry is not clear, it is difficult to accurately define the patent output indicators between enterprises. Therefore, this paper studies enterprise R \& D activities from the perspective of R \& D expenses. Refer to Dai Xiaoyong [11] for the definition of enterprise R \& D investment intensity, and define the R \& D investment intensity of the enterprise as the ratio of enterprise $\mathrm{R} \& \mathrm{D}$ expenditure to enterprise sales revenue. The larger the value, the higher the proportion of enterprise R \& D expenditure.

2) Core explanatory variables: corporate financial subsidies subsidy, the subsidy data comes from the non-recurring profit and loss items in the notes of the listed company's annual report-non-operating income-government subsidies included in the current profit and loss. If the annual report is not annotated, it is recorded as 0 . In the empirical model, the model needs to take the logarithm of the subsidy, which is represented by Insubsidy.

3) Enterprise size control variable: the total assets of the enterprise, Incapital, measure the size of the enterprise by counting the total assets of the enterprise. It is generally considered that the larger the enterprise, the weaker the dependence of $\mathrm{R} \& \mathrm{D}$ activities on government subsidies.

4) Enterprise debt level control variable: asset-liability ratio $d t a r$, which is the percentage of total corporate debt to total assets of the enterprise. This indicator reflects the proportion of assets provided by creditors in all assets of the enterprise, that is, the level of debt burden reflected by the enterprise.

5) The marketization level control variable of the enterprise: marketization index marketr. The data comes from Marketization Index of China's Provinces: NERI REPORT 2016 [12], in which the marketization index of the local provinces is determined according to the location of the enterprise registration, 
which reflects the local marketization level to some extent. This variable is used to control the impact of marketization levels on the strength of $\mathrm{R} \& \mathrm{D}$ spending.

6) Enterprise establishment period control variable: enterprise age, which is calculated from the period from the establishment of the enterprise to the experience of the year, and is used to control the potential impact of the establishment period of the enterprise on the proportion of $R \& D$ expenditure of the enterprise.

7) The actual tax burden control variable of the enterprise: the actual income tax rate taxr is used to measure the actual tax burden level of the enterprise. The data comes from the annual income tax expense of the annual income statement of the enterprise divided by the total profit before tax, to a certain extent. To measure the impact of corporate tax burden on R \& D activities. Since the company may have a loss, the income tax expense may be supplemented.

8) Corporate profitability control variable: ROE. In the capital market, ROE is generally used to measure the relative profitability of a company's invested capital, generally using the percentage of net profit and average net assets. Reflecting the return on investment of the company's owner's equity, the return on equity is used to measure the impact of corporate profitability on income.

Descriptive statistics for the main variables are shown in Table 1.

From the descriptive statistics of the main variables, the average R \& $\mathrm{D}$ expenditure of each enterprise is 2.5543 billion yuan, while the average R \& D investment intensity is $3.53 \%$, and the enterprise with the highest $\mathrm{R} \& \mathrm{D}$ investment intensity is $35.09 \%$. The average value of subsidies for new energy vehicle companies is 91.7248 million yuan, accounting for an average of $1.61 \%$ of total operating income.

\section{Research Design and Empirical Analysis}

\subsection{Research Model Design}

This paper plans to study the impact of financial subsidies on the R \& D intensity

Table 1. Descriptive statistics for each of the main variables.

\begin{tabular}{ccccc}
\hline Variable Name & Mean & Standard Deviation & Min & Max \\
\hline rdintensity & 0.0353 & 0.0328 & 0.0000 & 0.3509 \\
Insubsidy & 6.8411 & 1.6434 & 0.0000 & 9.6000 \\
Incapital & 21.7906 & 1.5365 & 17.5569 & 27.1045 \\
dtar & 0.4487 & 0.2138 & 0.0000 & 1.5613 \\
age & 13.7826 & 5.2872 & 1.0000 & 29.0000 \\
taxr & 0.0144 & 0.0303 & -0.1812 & 0.3058 \\
marketr & 7.8184 & 1.3558 & 3.9500 & 9.9500 \\
roe & 11.3110 & 0.1813 & -2.0086 & 1.1800 \\
\hline
\end{tabular}

Footnote: Only some of the main explanatory variables are shown. Data descriptive statistics are done through STATA14.0. 
of enterprises through the micro panel data of new energy auto companies. According to Chen Ling and Yang Wenhui [13], financial subsidies may have an incentive or "extrusion" effect on R \& D investment and innovation output of enterprises. Due to the limitation of data availability, this paper mainly studies the investment of financial subsidies on R \& D of enterprises. Therefore, here is the research hypothesis 1: Financial subsidies play a positive role in the $\mathrm{R} \& \mathrm{D}$ investment of China's new energy industry chain enterprises.

According to the results of the Hausman test, the Hausman Chi-square test value is 20.11 , and the $\mathrm{P}$ value is 0.0282 . The null hypothesis that the explanatory variable is not related to the residual term can be rejected at $5 \%$ confidence level. Therefore, this paper uses the Fixed Effects Model to estimate the explanatory variables and constructs the following model:

$$
\begin{aligned}
\text { rdintensity }_{i, t}= & \alpha+\beta_{1} \ln \operatorname{subsidy}_{i, t}+\beta_{2} \ln \text { capital }_{i, t}+\beta_{3} \text { dtar }_{i, t}+\beta_{4} \text { age }_{i, t} \\
& +\beta_{5} \operatorname{taxr}_{i, t}+\beta_{6} \text { markeketr }_{i, t}+\beta_{7} \text { roe }_{i, t}+\beta_{8} \text { timecontrol } \mu_{i}+\varepsilon_{i, t}
\end{aligned}
$$

Among them, $\alpha$ is the constant term, $\beta$ is the estimated coefficient of each explanatory variable, Timecontrol is the time dummy variable (where $i$ represents the individual, $t$ represents time, the same below), and $\mu_{i}+\varepsilon_{i, t}$ is the compound perturbation term of the fixed effect model, $\mu_{i}$ is an unobservable random variable, $\varepsilon_{i, t}$ is a disturbance term that changes with the individual and time. The model (1) is used to analyze the impact of financial subsidies on the overall $\mathrm{R} \& \mathrm{D}$ investment intensity of the industry. If the core explanatory variable coefficient is significantly positive, it indicates that the financial subsidy has a significant impact on the new energy vehicle industry as a whole.

Considering that different ownership enterprises (state-owned or private) may have different incentive effects on financial subsidies, this paper constructs dummy variables ownership p $_{i}$ to distinguish whether each enterprise is a state-owned enterprise. It should be noted that this article defines the state-owned enterprise as a state-owned capital holding enterprise. According to the development of new energy vehicle industry and the status quo of relevant industry policies in recent years, there is no clear evidence that state-owned capital enterprises have advantages in obtaining subsidies or investing in $\mathrm{R} \& \mathrm{D}$ in the process of promoting industrialization in the country. Based on this, this paper proposes Hypothesis 2: There is no significant heterogeneity in the role of financial subsidies in the R \& D investment activities of China's new energy industry chain enterprises.

In addition, considering that the new energy vehicle industry chain itself has sub-sectors, such as the vehicle manufacturing industry and key components (motor, battery, electronic control) manufacturing industry and special equipment manufacturing and sales industries, etc., different industries for research and development output The demand may be different. For example, the technology of the vehicle manufacturing industry is relatively mature and perfect, and the technical iteration cycle of the core components of new energy vehicles is relatively short. Therefore, the impact of financial subsidies on different sub-sectors may be heterogeneous. Therefore, this paper establishes the industry 
dummy variable industry $C_{i}$ : It indicates whether the industry belongs to the whole vehicle manufacturing industry, if it takes 1 , otherwise it takes 0 ; industry $B_{i}$ means whether the industry belongs to the core component of new energy vehicle (such as motor, battery, electronic control) Industry, if it is 1 , take 0 . On this basis, the research hypothesis 3 is proposed: financial subsidies may have significant heterogeneity on the $\mathrm{R} \& \mathrm{D}$ investment activities of different ownership enterprises in China's new energy industry chain.

Based on the above hypothesis, this paper additionally builds the following model:

$$
\begin{aligned}
& \text { rdintensity }_{i, t}=\alpha+\beta_{0} \ln _{\text {subsidy }_{i, t}}+\beta_{1} \text { ownership }_{i} * \ln \operatorname{subsidy}_{i, t}+\beta_{2} \ln \text { capital }_{i, t}+\beta_{3} \text { dtar }_{i, t} \\
& +\beta_{4} \text { age }_{i, t}+\beta_{5} \operatorname{taxr}_{i, t}+\beta_{6} \text { markeketr }_{i, t}+\beta_{7} \text { roe }_{i, t}+\beta_{8}{\text { timecontrol }+\mu_{i}+\varepsilon_{i, t}} \\
& \operatorname{rdintensity}_{i, t}=\alpha+\beta_{0} \ln \operatorname{subsidy}_{i, t}+\beta_{1} \text { industry } C_{i} * \ln \operatorname{subsidy}_{i, t}+\beta_{2} \ln \text { capital }_{i, t}+\beta_{3} \text { dtar }_{i, t} \\
& +\beta_{4} \operatorname{age}_{i, t}+\beta_{5} \operatorname{taxr}_{i, t}+\beta_{6} \text { markeketr }_{i, t}+\beta_{7} \text { roe }_{i, t}+\beta_{8} \operatorname{timecontrol}+\mu_{i}+\varepsilon_{i, t} \\
& \text { rdintensity }_{i, t}=\alpha+\beta_{0} \ln _{\text {subsidy }}+\beta_{1, t}{\text { industry } B_{i}} * \ln \operatorname{subsidy}_{i, t}+\beta_{2} \ln \text { capital }_{i, t}+\beta_{3} \text { dtar }_{i, t} \\
& +\beta_{4} \text { age }_{i, t}+\beta_{5} \operatorname{taxr}_{i, t}+\beta_{6} \text { markeketr }_{i, t}+\beta_{7} \text { roe }_{i, t}+\beta_{8} \operatorname{timecontrol}+\mu_{i}+\varepsilon_{i, t}
\end{aligned}
$$

The cross-term coefficients in models (2), (3), and (4) are used to measure ownership and the impact of industry heterogeneity. If the core explanatory variables and the interaction coefficient are significantly positive, then the ownership or industry heterogeneity has a significant impact on the effect of financial subsidies. The above models all use robust standard errors.

\subsection{Empirical Analysis}

The empirical results are shown in Table 2.

From the regression results (1), (2), (3), (4), the regression coefficients of the main variables of the corresponding model can be obtained. According to the regression results (1), the financial situation can be obtained under the control time and individual effects. The subsidy logarithm is significantly positive for the $\mathrm{R} \& \mathrm{D}$ investment intensity of China's new energy auto companies at a confidence level of $1 \%$, with a coefficient of 0.0038 , that is, financial subsidies have a positive stimulating effect on $\mathrm{R} \& \mathrm{D}$ investment activities of new energy auto companies; Results (2) can be concluded that the coefficient of interaction between ownership and financial subsidies is not significant, thus demonstrating that the effect of ownership differences on financial subsidies is not significant; from the regression results (3), (4), financial subsidies for different segments of industry There are significant differences in the effects of R \& D activities in enterprises. The effect is not significant for the new energy vehicle manufacturing industry, but it is more effective for the core components manufacturing industry of new energy vehicles. The effect of financial subsidies is industrial heterogeneity. From the regression results of other control variables, the longer the establishment of the enterprise, the greater the intensity of R \& D investment. To some extent, it proves that the maturity of the development of the enterprise has certain influence on its own R \& D intensity. 
Table 2. Analysis of regression coefficient of financial subsidy to China's NEV industry R \& D investment intensity.

\begin{tabular}{|c|c|c|c|c|}
\hline Variables & (1) & $(2)$ & (3) & $(4)$ \\
\hline \multirow[t]{2}{*}{ Insubsidy } & $0.0038^{\star * *}$ & $0.0036^{*}$ & $0.0033^{* *}$ & $0.0023^{*}$ \\
\hline & $(0.0013)$ & $(0.0019)$ & $(0.0016)$ & $(0.0012)$ \\
\hline \multirow[t]{2}{*}{ ownership*lnsubsidy } & & 0.0005 & & \\
\hline & & $(0.0021)$ & & \\
\hline \multirow[t]{2}{*}{ industry $C \times \ln s u b s i d y$} & & & 0.0023 & \\
\hline & & & $(0.0017)$ & \\
\hline \multirow[t]{2}{*}{ industry $B \times \operatorname{lnsubsidy}$} & & & & $0.0055^{\star *}$ \\
\hline & & & & $(0.0022)$ \\
\hline \multirow[t]{2}{*}{ Incapital } & -0.0053 & -0.0052 & -0.0047 & -0.0060 \\
\hline & $(0.0037)$ & $(0.0037)$ & $(0.0039)$ & $(0.0039)$ \\
\hline \multirow[t]{2}{*}{ age } & $0.0074^{* *}$ & $0.0074^{* *}$ & $0.0073^{* *}$ & $0.0073^{* *}$ \\
\hline & $(0.0033)$ & $(0.0033)$ & $(0.0033)$ & $(0.0033)$ \\
\hline \multirow[t]{2}{*}{$\operatorname{tax} r$} & -0.0519 & -0.0525 & -0.0566 & -0.0503 \\
\hline & $(0.0368)$ & $(0.0367)$ & $(0.0356)$ & $(0.0364)$ \\
\hline \multirow[t]{2}{*}{ marketr } & -0.0077 & -0.0077 & -0.0077 & -0.0074 \\
\hline & $(0.0100)$ & $(0.0100)$ & $(0.0100)$ & $(0.0100)$ \\
\hline \multirow[t]{2}{*}{$d t a r$} & 0.0134 & 0.0132 & 0.0124 & 0.0173 \\
\hline & $(0.0134)$ & $(0.0135)$ & $(0.0134)$ & $(0.0138)$ \\
\hline \multirow[t]{2}{*}{ roe } & -0.0124 & -0.0125 & -0.0123 & -0.0135 \\
\hline & $(0.0082)$ & $(0.0081)$ & $(0.0083)$ & $(0.0091)$ \\
\hline \multirow[t]{2}{*}{ Constant term } & 0.0696 & 0.0684 & 0.0577 & 0.0776 \\
\hline & $(0.0984)$ & $(0.0989)$ & $(0.1025)$ & $(0.1011)$ \\
\hline Model & Static FE & Static FE & Static FE & Static FE \\
\hline Time effect & controlled & controlled & controlled & controlled \\
\hline $\mathrm{N}$ & 615 & 615 & 615 & 615 \\
\hline
\end{tabular}

Footnote: The significance level in the table, "*” indicates that the $\mathrm{p}$ value of the corresponding statistic is less than 0.1 , “**” means $p$ is less than 0.05 , “***” means $p$ is less than 0.01 , the same below.

\subsection{Robust Test}

For the model itself or the possible heteroscedasticity caused by the missing important variables of the model, and the endogeneity of the model itself, further testing is needed. For the heteroscedasticity problem, the white test and the Breusch-Pagan test are performed on the model (1), in which the white test statistic is 29.65 , the $P$ value is 0.27 , and the null hypothesis of the same variance cannot be rejected; the BP test statistic is 3.60 , P value 0.0527 At the $10 \%$ significance level, the null hypothesis can be rejected and there may be heteroscedasticity. For the above problems, refer to the practice of the previous literature, introduce the independent variable and the dependent variable lag term as the dif- 
ference, use the system generalized moment estimation (SYS-GMM) method for the estimation, the model AR (2) test statistic p value is 0.585 , no The null hypothesis that there is no second-order sequence autocorrelation is rejected, indicating that the second-order or higher-order lag term can be used as the GMM-type instrumental variable; the Hansen statistic is 49.89 , and the p-value is 0.113 , indicating that the GMM-type instrumental variable is relatively effective. In addition, the results of the dynamic panel fixed-effects model with the lag phase are used as reference. The results are shown in Table 3.

In Table 3, l.rdintensity represents the lag of the enterprise's $\mathrm{R} \& \mathrm{D}$ investment intensity. It can be seen that the effect of financial subsidies on $\mathrm{R} \& \mathrm{D}$ investment of enterprises is still significant when considering the lag item. It can be considered that the results are robust under this condition.

\section{Conclusions and Policy Recommendations}

This paper uses 75 new energy vehicle listed companies in 2008-2016 as a research sample to analyze the relationship between government financial subsidies and $\mathrm{R} \& \mathrm{D}$ intensity. On the whole, there is a significant linear positive correlation between financial subsidies and the intensity of $R \& D$ investment in

Table 3. Dynamic panel regression results.

\begin{tabular}{|c|c|c|c|}
\hline Variables & (1) & (2) & (3) \\
\hline \multirow[t]{2}{*}{ Insubsidy } & $0.0038^{* * *}$ & $0.0041^{\star * *}$ & $0.0077^{* * *}$ \\
\hline & $(0.0013)$ & $(0.0012)$ & $(0.0023)$ \\
\hline \multirow[t]{2}{*}{ 1.rdintensity } & & $0.4007^{\star * *}$ & $0.5761^{\star * *}$ \\
\hline & & $(0.1314)$ & $(0.1852)$ \\
\hline \multirow[t]{2}{*}{ Incapital } & -0.0053 & $-0.0104^{\star \star *}$ & $-0.0115^{\star}$ \\
\hline & $(0.0037)$ & $(0.0032)$ & $(0.0061)$ \\
\hline \multirow[t]{2}{*}{ age } & $0.0074^{\star \star}$ & $0.0041^{*}$ & 0.0000 \\
\hline & $(0.0033)$ & $(0.0021)$ & $(0.0007)$ \\
\hline \multirow[t]{2}{*}{$\operatorname{tax} r$} & -0.0519 & -0.0455 & 0.2812 \\
\hline & $(0.0368)$ & $(0.0357)$ & $(0.2491)$ \\
\hline \multirow[t]{2}{*}{ marketr } & -0.0077 & -0.0087 & 0.0003 \\
\hline & $(0.0100)$ & $(0.0064)$ & $(0.0021)$ \\
\hline \multirow[t]{2}{*}{ dtar } & 0.0134 & $0.0246^{\star *}$ & -0.0021 \\
\hline & $(0.0134)$ & $(0.0111)$ & $(0.0123)$ \\
\hline \multirow[t]{2}{*}{ roe } & -0.0124 & -0.0088 & -0.0144 \\
\hline & $(0.0082)$ & $(0.0063)$ & $(0.0184)$ \\
\hline \multirow[t]{2}{*}{ Constant term } & 0.0696 & $0.2258^{\star * *}$ & $0.2137^{*}$ \\
\hline & $(0.0984)$ & $(0.0802)$ & $(0.1212)$ \\
\hline Model & Static FE & Dynamic FE & SYS-GMM \\
\hline $\mathrm{N}$ & 615 & 550 & 550 \\
\hline
\end{tabular}


enterprises. That is, government subsidies are conducive to promoting $\mathrm{R} \& \mathrm{D}$ activities of enterprises, thereby ultimately improving the overall technical level of enterprises; analyzing by industry. The core component in new energy vehicle industry's R \& D investment effect is obvious, but the effect on the final product, i.e., vehicle assembly and production, is not significant; the effect of financial subsidies for $\mathrm{R} \& \mathrm{D}$ investment of new energy auto companies with different ownership is not significantly different. There is a significant positive correlation with the intensity of $\mathrm{R} \& \mathrm{D}$ investment in enterprises with different year of establishment.

Based on the current status of policy implementation, this paper proposes several relevant policy recommendations for the formulation and revision of subsidy policies for new energy auto companies from the conclusion of the study: first, it is necessary to affirm the effect of financial subsidies in promoting new energy vehicles to improve $\mathrm{R} \& \mathrm{D}$ activities, but the direction of investment still needs to be further refined to improve the efficiency of the use of subsidy funds. Especially under the premise that the current stimulation effect of new energy vehicle production has been basically achieved, the conditions for subsidy payment can be refined, such as improving the new energy vehicle. The technical threshold for subsidies, such as the need to achieve certain power consumption indicators and cruising range, for low-tech vehicles and components should be gradually eliminated through a completely market-based approach; secondly, it is necessary to focus on supporting new intellectual property rights in China. And targeted subsidy policies for new energy vehicle core component manufacturers should be formulated to promote technological upgrades of the new energy vehicle industry. For some R \& D activities of core energy technologies for new energy vehicles with long development cycles and high externalities, additional activities are required. Furthermore, we need to establish and improve market supervision mechanisms and intellectual property protection mechanism to prevent the continuation of a "cheat up" phenomenon and vicious market competition.

Due to the limitations of data and measurement methods, the research depth of this paper still has limitations. The effect of financial subsidies has not been analyzed from the perspective of R \& D output. Therefore, further research is needed, and other new energy auto industries may be promoted. The factors of R \& D innovation still need to be further expanded.

\section{Conflicts of Interest}

The author declares no conflicts of interest regarding the publication of this paper.

\section{References}

[1] Griliches, Z. (1990) Patent Statistics as Economic Indicators: A Survey. Journal of Economic Literature, 28, 1661-1707.

[2] Arrow, K.J. (1962) Economic Welfare and the Allocation of Resources for Inven- 
tion. Universities-National Bureau Committee for Economic Research. Committee on Economic Growth of the Social Science Research Council, 609-626.

[3] Chen, Z.J. (2017) Fiscal Competition, Spatial Strategy Behavior and Enterprise Technology Innovation among Local Governments. Financial Research, No. 8, 69-78.

[4] Chen, Y.F. and Li, J.C. (2011) The Impact of Government R \& D Funding on Corporate R \& D Funding: An Empirical Analysis Based on Panel Data of Industrial Enterprises above Designated Size in Zhejiang Province. Business Economics and Management, No. 2, 30-36.

[5] He, Y.L. and Zhu, W.H. (2017) The Impact of Financial Subsidy on R \& D Investment-Based on the Perspective of Government-Enterprise Relationship. Research on Science and Technology Management, No. 11, 28-36.

[6] Wang, Z. (2014) Research on the Performance of Chinese Government's Innovation Subsidies for Strategic Emerging Industry Companies. Master's Thesis, Hunan University, Changsha.

[7] Gao, H.W. (2011) Research on the Extrusion Effect of Financial Subsidy on the R\&D of Large State-Owned Enterprises. China Science and Technology, No. 8, $15-20$.

[8] Guo, X.D. and He, W.Z. (2011) Dynamic Analysis of the Signal Effect of R \& D Subsidy in Strategic Emerging Industries. Economic History, No. 11, 63-69.

[9] Chu, D.Y., Yang, W. and Song, G.M. (2016) Fiscal Competition, Spatial Strategy Behavior and Enterprise Technology Innovation among Local Governments. Finance and Trade Research, No. 5, 83-89.

[10] Dai, C. and Liu, Y. (2008) A Comparative Analysis of the Impact of Tax Incentives and Financial Subsidies on Enterprises. Economic Science, No. 3, 58-71.

[11] Dai, X.Y. and Cheng, L.W. (2014) The Threshold Effect of Financial Subsidy Policy on Enterprise R \& D Investment. Science Research Management, No. 6, 69-76.

[12] Wang, X.L., Fan, G. and Yu, J.W. (2017) Marketization Index of China's Provinces: Neri Report 2016. Social Science Academic Press (China), Beijing.

[13] Chen, L. and Yang, W.H. (2016) Will Government R \& D Subsidies Promote Enterprise Innovation?-An Empirical Study from Chinese Listed Companies. Science Research, No. 3, 434-442. 